\title{
Wither the South on Screen: Revisiting Some Recent Releases
}

\begin{abstract}
My article deals with the construction of a different South on screen in the posthuman context. It focuses on the way previous idealized embodiments of the South on film are being displaced to give way to an alternative South on screen informed by our contemporary aesthetics characterized by violence and human reification. The filmic South increasingly coheres with the historical South through the rewriting of formulaic tropes such as the plantation, the Southern belle and gentleman, and the staging of significant historical moments such as the Nat Turner rebellion and the Civil War. Recent releases perform national cultural work at a time when the demons of Southern history have come back to haunt the national imagination, as recent events such as the shooting at Immanuel church (June 2015) and Charlottesville (October 2017) have tragically shown.
\end{abstract}

Keywords: Southern plantation; Southern belle; Southern gentleman; the Civil War; No Country for Old Men (2007); The Road (2009); Django Unchained (2012); The Counselor (2013); The Hateful Eight (2015); The Birth of a Nation (2016); The Beguiled (2017); The Mule (2018).

"A cautionary diamond"

Film provides a unique way to transform reality into a narrative, and cinema often performs urgent cultural work, with an increasingly cautionary or parabolic dimension. The embodiment of the American South on screen has frequently departed from historical reality, and is used instead to voice certain national concerns and obsessions. The cinematic South has been associated either with a golden age and an idyllic land in keeping with the fantasies of plantation fiction, or with a corrupt land of evil degenerates; one version or the other is emphasized to perform cultural work within a national agenda. Staging the American South has thus traditionally involved proposing two contradictory depictions of the South - "Angel or Demon" as I put it in an earlier article ${ }^{2}$ - while constructing different Souths on screen. The casting of the South as a decadent and fallen land came to dominate the movie production after the Civil Rights era when television images exposed a violent South to the national consciousness. They indeed revealed a form of societal madness - what Lillian Smith describes in Killers of the Dream as the "schizophrenia of a South pathologically sick with physical and symbolic violence" (Smith 22). The pioneering work done on the topic of the South on screen by scholars such as Edward Campbell, Warren French, and Jack Temple Kirby, ${ }^{3}$ has been followed by an ever-growing body of scholarship

1 The Amsterdam jewel merchant to the counselor in The Counselor.

2 See "Angel or Demon: Performing the South in Cinema," in Le Sud au cinéma, p. 37-53.

3 Edward D.C. Campbell Jr., The Celluloid South: Hollywood and The Southern Myth, Knoxville, The University of Tennessee Press, 1981; Warren French, ed, The South and Film, Jackson, University Press of Mississippi, 1981; Jack Temple Kirby, Media-Made Dixie: The South in the American Imagination, Baton Rouge, Louisiana State University Press, 1978. See also the special issue of The Southern Quarterly 19.4 (1981) titled The South and Film. 
dealing with the filmic South. ${ }^{4}$

Recent releases revolving around the American South (through biopics in particular) and/or its History are characterized by a form of rewriting of traditional tropes, characters and settings. ${ }^{5}$ Instead of rehearsing well-known individual and collective stories, they create an array of new images closer to the historical reality than previous (idealized) images of the South on screen. In addition, they resort to graphic violence and the grotesque mode, illustrating the poetics of our posthuman context, in particular its aesthetics of fragmentation and distortion - an era of "organs without bodies," to use Rosa Braidotti's image. ${ }^{6}$ The cinematic South thus increasingly coheres with the historical South while current releases continue to perform national cultural work at a time when the demons of Southern history have come back to pervade the collective imagination, as recent events such as the shooting at Immanuel Church (June 2015) and the eruption of violence at Charlottesville (August 2017) have tragically shown.

The political dimension of the screen South often engages with a discourse on gender, race and class. Icons of choice include the plantation and its attending representation of slavery/the racial question, the Southern belle and gentleman, and the topic of the Civil War. The filmic South is characterized by the enduring legacy of both the gothic script of the conflict between good and evil, and the aesthetics of the grotesque, in particular the mutilated and distorted body as a trope for dysfunctional cultural elements. The characters and situations feature degeneracy and corruption, decadence and collapse; the physical and/or mental distortions figure the societal distortions of a region haunted by a legacy of racial violence and injustice. Cultural aberrations find in natural aberrations the sign of their "monstrosity" - the realm of the abject - and horror: the signifier to a signified that is conjured up stubbornly and viscerally.

This article focuses on the way these formulaic elements have been revisited and rewritten in recent productions. Texas, in particular, has become the state of choice for the setting, perhaps ousting Mississippi as the preferred backdrop. What do these productions tell us? What do these choices reflect? We will analyze the aesthetic and cultural modalities of these film poetics through an analysis of the following movies: Ethan and Joel Coen's No Country for Old Men (2007), Quentin Tarentino's Django

4 See for instance Karl G. Heider, ed, Images of the South: Constructing a Regional Culture on Film and Video, Athens and London, The University of Georgia Press, 1993; Larry Langman and David Ebner, eds, Hollywood's Image of the South: A Century of Southern Films, Westport, Greenwood Press, 2001; Allison Graham, Framing the South: Hollywood, Television, and Race during the Civil Rights Struggle, Baltimore and London, The Johns Hopkins University Press, 2001; Helen Taylor, Circling Dixie: Contemporary Southern Culture Through a Transatlantic Lens, Piscataway, Rutgers University Press, 2001. In France, the first book on the topic was Le Sud au cinéma: de The Birth of a Nation à Cold Mountain, Marie Liénard-Yeterian and Taina Tuhkunen, eds, Palaiseau, Editions de l'Ecole polytechnique, 2009.

5 Numerous examples could be given in the post 9/11 era. Here is just a sample: Cold Mountain, The Changeling, No Country for Old Men, Wild Beasts of the South, Mud, Lincoln, Django Unchained, The Counselor, The Hateful Eight, Loving, Mudbound, Twelve Years a Slave, The Beguiled, The Birth of a Nation ...

6 See in particular her book The Posthuman, Cambridge and Malden, Politi Press, 2013. 
Unchained (2012) and The Hateful Eight (2015), Ridley Scott's The Counselor (2013), Nate Parker's The Birth of a Nation (2016), and Sofia Coppola's The Beguiled (2017). Passing remarks will also be made to John Hillcoat's The Road (2009) and its Southern mansion sequence, and to Clint Eastwood's The Mule (2018) and its handling of Texas as a significant backdrop.

\section{Texas Unchained: Southern Mystique and Western Myth ${ }^{7}$}

The South and its "obscure intertwining of destructive and ineluctable forces" in Edouard Glissant's image in his book Faulkner, Mississipppi, is increasingly symbolized by Texas, the New Old South. In an article titled "Big Dangers for the Next Election," Elizabeth Drew explains: "The Texas ID law accepted concealed-carry permits but not state-issued student ID." "She adds: "No sooner did the Shelby decision come down than a number of jurisdictions rushed to adopt new restrictive voting laws in time for the 2014 elections - with Texas in the lead" (Drew 21). As she stresses, "In 2013 the Supreme Court, by a 5-4 vote, gutted the Voting Rights Act. In the case of Shelby v. Holder, the Court found unconstitutional the sections requiring that states and regions with a history of voting discrimination must submit new voting rights laws to the Justice Department for clearance before the laws could go into effect" (Drew 21).

As a border between different Souths, and the site where global issues of drug wars and human trafficking are raging, Texas reprises the wild violence of the Frontier - a moving line of un-civilization. As a screen object, Texas is poised at the intersection of both the legacy of the South with its slave-owning past, and the Western myth. Current conflicts over power and territory, and their new players/outlaws, is explored as a way to probe into the topical issues of greed and exploitation in all its guises and forms. Texas constitutes a borderland between South and West where the foundational mythologies of the American experience are conjured up to expose the ills of deadly trades, including human trafficking. ${ }^{9}$ Recent representations of the Texan South trail blaze new grounds for the terrors of our times - a landscape of human and natural disaster.

Therefore, films such as No Country for Old Men and The Counselor (with a script by Cormac McCarthy), and Django Unchained (the opening sequence takes place in Texas before moving to the more conventional territory of Mississippi) testify to the creative encounter between images of the Western and iconic elements of the embodiment of the South on screen. These movies, to use Gary Helm Darden's phrase in a 2009 article published in The Southern Quarterly titled "The New Empire in the

7 A recent collection of essays When the West Meets the South on Screen has reprised the title of one of my conference abstracts South meets West and my inquiry into the generic encounters between Southern and Western (as already analyzed in my article on No Country for Old Men titled "No Country for Old Men de Cormac McCarthy: Des mots aux images"), it is published by the Revue LISA (vol XVI. 1, 2018).

8 In "Big Dangers for the Next Election." New York Review of Books vol. LXII. 9 May 21-June 3, 2015 titled (20-22), p. 20.

9 Cormac McCarthy explored the contradictory symbolism of the road in his eponymous novel: the road leads nowhere but to death. 
'New South': Jim Crow in the Global Frontier of High Imperialism and Decolonization," involve "connecting pivotal moments in the history of the South with a larger global narrative" (Darden 12) - in this case, the dystopian narrative of increasing internecine wars in the wake of what is now called the "global order." 10 Such imagery provides new thematic and formal territories for the Southern gothic while chartering alternative forms of Southern decadence. They beget another South in and for the American cultural imagination. In the film adaptation of Cormac McCarthy's novel No Country for Old Men by Joel and Ethan Coen, for example, the haunted space is the rugged and desolate ecosystem of the desert as opposed to the formulaic swamp or woods. This "survivalist landscape" as the Coen brothers call it, emblematizes the corruption of the environment under human encroachment; it is a battlefield for emerging forms of war and conflict over money and property waged by drug cartels who have replaced plantation owners as the cruel and ruthless masters.

In 2013, Cormac McCarthy returned to Texas land with a movie script for The Counselor. Some of the dialogues in The Counselor take on a prophetic or parabolic ring, such as the Amsterdam jeweler's presentation of diamonds and their "cautionary" dimension, or the Mexican lawyer's take on Antonio Machado's poetry. Through such elements and characters, McCarthy illustrates what Richard Gray calls in his book $A$ Web of Words the South's "trademark theme" of the "compulsion to turn life into telling" (Gray 220). He tackles the theme of human regression he had already addressed in The Road by suggesting how bodies are items to be used, enjoyed (sometimes in a sadistic way), consumed (as in The Road) or discarded. Props such as the bobino (the collar that slowly tightens around the victim's neck) or the DVD, and preposterous scenes such as the "lovemaking" to the car, function as sites of exposure: they address the fact that human beings are handled like commodities in a world where material goods are worshipped idols. In addition, the movie bodies forth the way women, like cars, are prized but disposable status symbols. Last but not least, the bobino death sequence interpolates the interaction between media and terrorism: the slow and graphic death caused by the collar slowly but relentlessly choking the human neck orchestrates a spectacular show of horror that evokes our contemporary world of terror mediated by images spread over our ubiquitous screens.

Clint Eastwood's The Mule (2018) focuses on another axis - both border and frontier: the South/North route. This vertical trajectory evokes additional historical events associated with the legacy of the Antebellum South: the Great Migration or massive northward exodus of African-Americans between 1916 and 1970, the "Southern diaspora," as James Gregory called it, which actually started at the turn of the century. Clint Eastwood stages the well-known drama of the drug trade through the portrait of a Korean War veteran turned "drug mule" and working for one of the Mexican cartels. His war record highlights the fact that drug trafficking involves novel and native forms of warfare, with equally numerous casualties and losses as a result of total violence. Like The Counselor, The Mule presents the female body as a desirable but disposable and exchangeable commodity, a status symbol and gift reinforcing male

10 Such imagery was reprised in a recent movie by Algerian-born Rachid Bouchared titled La voie de l'ennemi where Texas is used as a trope to address the current state of Algeria torn apart by sectarian conflicts and deadly violence. 
bonding. Some of the Texas shots show the barren and desolate landscape analyzed above; the fragile and beloved flowers grown by Earl's horticultural skills constitute a tragic reminder of a beauty that cannot survive in the scorching sun of Texas land some expenditure of love that will die with Earl.

\section{The Southern Plantation Unchained}

Screen representations of the plantation date back to the idealized vision narrated in the plantation novel, and the imagery popularized most blatantly by Gone with the Wind - a world where gentility and good manners prevail, along with peaceful relations between masters and slaves. Quentin Tarantino's Django Unchained proposes a full plantation "redux": what had remained concealed in the other tales - the "powers of horror" described by Julia Kristeva in her eponymous book - is exposed in a merciless light. In the 2012 film, cameo shots such as the close-up on the cotton ball stained by blood, provide iconic texts that encapsulate the story of plantation life - the crimson color, like a scarlet letter, branding the South as cruel and murderous. ${ }^{11}$

Tarantino resorts to his trademark use of extreme violence to deconstruct the cruel mechanics of the plantation economy - physical and symbolic. The term "Unchained" brings the viewer back to John Boorman's 1972 movie Deliverance that so boldly engaged with the borderland between civilization and savagery, "unchaining" the Wild South for the screen. Moreover, Django Unchained engages with the theme of performance - and the theatrics of race, class and gender underpinning Southern culture. The trope of passing - which exposes the reversibility of the categories and their porous boundaries, and denounces their arbitrariness - is explored in its multifaceted reality: passing for a gentleman, passing for a slave merchant, and passing for a valet.

The script proceeds through a series of cameo scenes, revisiting iconic moments in the plantation story while probing into the logic of the plantation system. Tarantino skillfully blends gothic and grotesque elements, such as Django's blue costume, the temporal and spatial incongruity of which points to the fact that the kind of aristocracy upheld by the planters reprised former moments of historical cruelty in the "Old World." The long quest to reach the plantation is a prelude to the initiatory journey on the grounds of the plantation - a rite of passage that includes the terrifying sequence of the Mandingo fight, and the ultimate alienation from human empathy and affect. The welcoming of Schultz and Django alludes to the fact that many foreign visitors toured the Antebellum South indeed, in particular from Germany. The guests were frequently shocked by what they discovered, and their stay on the plantations, however short, shattered their illusions about the "Southern way of life."

Moreover, Django Unchained probes into other forms of cruelty that had not been addressed on screen yet, in particular the choreographed tearing of human flesh, and its attending horror supplemented by terror which Stephen King defines as "what the mind sees." These graphic episodes provide a mise en abyme for the ubiquitous gore informing our contemporary imagination through our consumption of extremely

11 Twelve Years a Slave (2013) reprises some moments of the chilling staging of the ruthless plantation machine. 
violent images through open access on the Internet and social media. The Mandingo fight to death and the destruction of the aging slave by the master's dogs not only constitute chilling examples of the handling of the slave's body in the Antebellum South but also perform the agency of the voyeurism involved in the practice of lynching. Lynching indeed entailed a choreographed ritual of violence that required a public: to become a spectator was the token of belonging. In addition, the grotesque aesthetics of the fragmented body speaks of the abjection attached to the lynched body; the breaking of the bone functions as a synecdoche for both the horror and horror of the breaking of humanity - then and now.

Tarantino uses the traditional elements of the plantation story, and their attending imagery such as the mansion and its porch, and the formulaic gallery of protagonists: the sophisticated master and his sibling, the overseer in the fields, the faithful and loyal butler, the slaves, the terrifying dogs. The script rehearses a lot of the conventional elements of the plantation narratives such as the fine distinction between house and field slaves, the female slaves' sexual enslavement, the institution of terror through the implementation of public spectacles of cruel punishments, and the importance of the kitchen as the space mediating between the slaves' world and the masters' world. The filmmaker also addresses the ideological framework of the "peculiar institution" by referring to the craniologists' theories about the races in the dinner sequence at the plantation.

Through and beyond his characteristically graphic sequences, Tarantino proposes a full exploration of the overall dehumanizing process induced by chattel slavery; the character of the butler, for example, illustrates the self-loathing figure who betrays his own race to hold on to the little power he has managed to establish in the household. The savagery of the dogs functions as an extension of the pervasive politics of terror, as the recent novel Sing, Unburied, Sing by Jesmyn Ward also narrates in a powerful way. ${ }^{12}$ The bond between Calvin Candie and his sister fits within the topos of incest as used by Edgar Allan Poe and William Faulkner for example, in particular as a sign of the endogamy perpetuated by the plantation class system. The violence within the household, and the burning of the house, also revisit previous representations of the collapse of such dynasties in literature, as narrated in "The Fall of the House of Usher" or Absalom, Absalom!, and, on screen, most famously in the crane shot of the city of Atlanta on fire in Gone with the Wind.

Another recent release - Ridley Scott's 2013 The Counselor, with a script by Cormac McCarthy - takes up in modern times the destructive logic of the plantation economy. McCarthy had already explored the topos of the Southern mansion as a way to address the legacy of historical violence and corruption in his novel The Road in a scene reprised in the 2009 film adaptation by John Hillcoat. The most gruesome sequence of the narrative takes place in the South, when the father and his son accidentally discover a human pantry in the cellar of a big house. The Southern home is haunted, like its formulaic models, by the legacy of murder and human reification that

12 One of the narrative threads in Ward's 2017 novel involves the embedded story told by Pop to his grandson Jojo about his time at Parchman where he witnessed many killings of run away prisoners by dogs chasing after them; he also tells about how he tried to protect his friend Richie from such a fate. 
is rendered literal through the trope of cannibalism. Terror and horror - the traditional ingredients of the Southern gothic in cinema and in literature - are mobilized to stage this chilling moment in the novel that breaks new ground in the embodiment of the South on screen through its overall science-fictional/apocalyptic framework.

In The Counselor, the Antebellum enslavement of the human body is addressed through its contemporary guises, in particular human trafficking and pornography. These current forms of abuse and slaughter evoke chattel slavery; its practice of torture as a mode of terror is intuited through significant elements such as snuff movies and the bobino collar. The body - female in particular - is the locus of violence, now as it was then. Worshipped and adored at the beginning (as shown in the opening erotic scene), it will be dumped later in a landfill - a frightening reminder of the legacy of other bodies dumped into the laborious machine of the plantation economy - anonymous or defaced cogs in a ruthless system. The numerous workers involved in the business (the truck drivers, the dealers, the cleaning ladies and the bikers carrying the money, to name just a few) form a modern cohort of enslaved labor that can be disposed of with the same impunity as in the Antebellum South. The purity of the diamond marred by a flaw tells an early parable which later functions as a cautionary tale, revisiting the moral dimension of the gothic mode that pervades the gothic mode.

By the end of the movie, however, the title sounds tragically ironic: the counselor and his legal world are powerless to uphold order in a lawless world of endemic corruption. The movie offers indirect but intense coverage of all drug-related activities, including mass graves in the midst of trash, inscribing the formulaic theme of haunting into the larger repertoire of twentieth century horror and imagination of disaster. Such imagery calls to mind one of the scenes of James Lee Burke's novel In The Electric Mist with the Confederate Dead when detective David Robichoux explains to General John Bell Hood as he encounters him in the Louisiana swamp: "The times you lived in were different general. This afternoon I watched a film that showed young women being beaten and tortured, perhaps even killed, by sadists and degenerates. This stuff is sold in stores and shown in public theatres" (Burke 317). The proper-counselor-turned-lawless outcast receives an emblematic prop from the cruel world he has compromised with: the DVD with the greeting Hola inscribed on it is all that is left of his "chivalric romantic life." But he is no Petrarch, and his purchase of an expensive diamond he could not afford has triggered a fatal curse and a chase. No deus ex machina will come to the rescue and bring closure to this tale full of sound and fury. Codes of interaction and survival dictated by greed and profit result in abnormal forms of human behavior and purpose; they work as reminders of how so-called "codes of honor" in the South perverted moral imperatives regarding human dignity and respect, and used Divine Law to justify abject practices such as slavery and lynching. The handling of the body in snuff movies recalls the transgression performed through breaking the boundary between objects and humans.

\section{Southern Belles and Gentlemen: Performing Without the Mask(s)}

The representation of the body is situated at the intersection of the depiction of the plantation and the attending protagonists: the Southern belle and gentleman. In 1939, 
Gone With the Wind set the paradigm for the representation of the Southern belle. Tara McPherson, in her book Reconstructing Dixie, analyzes the "staying power" of the belle in the literary and filmic imagination. The recent image proposed by Sofia Coppola in The Beguiled revisits, and rewrites, some of the features and dimensions of the belle's persona. Coppola's version (compared to the earlier adaptation by Don Siegel in 1971), with its bold exploration of female desire and sensuality, introduces the type's repressed or silenced sexual dimension to stage a Lady who acts on her passions and longings. The script tropes the formulaic gothic dynamic of the male bully and the female victim, turning traditional gender power relations into a dialectic - a finely tuned but fragile balance than can be destroyed or reversed: like mushrooms, the belle can be nurturing or deadly.

The film has the compression and tension of Sartre's No Exit (Huis Clos). The plantation house and its garden remind the viewer of the opening paragraph of "The Fall of the House of Usher" with the outsider ushred into a "house." Violence is kept at bay even though it remains a threat and obsession, as the camera work indicates in the striking opening scene. At first, the viewer is lured into the script of men and women falling in love, relying on the conventional notions of gentility and seduction. The women showcase the paraphernalia of ladyhood, however incongruous the hoop skirt and fancy hairdo might have become in the war context, when ladies are required to do the hard work previously done by slaves.

Yet, the keepers of the Southern home welcome into their place and space the enemy that "their" men have been fighting, showing some disloyalty to the very cause they are supposed to support and uphold. Other forms of subversion appear: the ritual associated with the evening prayer is changed into a ritual of courtship, and attention is deflected away from the transcendent to the material level of the body. Gradually, the plot unfolds a deadly drama of jealousy, retaliation and murder. The final scene, when the camera moves away from the body bag on the other side of the gate, presents a haunting image of the ambivalence of the South towards sexual desire, and the uncanny effect of women's gentility turned deadly.

An alternative image of the Southern belle undergoes further exploration in The Counselor in the context of another century and another type of war. Ridley Scott's movie proposes two avatars of the formulaic figure set against the backdrop of what we can call a New Antebellum South. First, Laura's character upholds some of the traditional features in terms of beauty and class, and the white color of the opening scene alludes to the purity associated with her idealized image. Like the diamond she is given, she becomes - in a long line of previous models in literature and cinema - an expensive commodity sacrificed to uphold a certain order: her body takes on symbolic value to reinforce a form of patriarchy (in this context, Cartel rules of retaliation and business ventures) - and she becomes material for the prized snuff movie industry undergirding cartel profit-making and rule of terror. A terrible warning that sounded like a bad omen had been issued early on by another protagonist, perhaps a repentant gentleman catering to the damsel-in-distress-to-be. But she had paid no attention, having fallen under the spell of her own romantic ideal and quest. Her beau, unfortunately, learns too late that she is not just an expensive piece of jewelry that can be traded but a human being who cannot be replaced. Like Blanche DuBois, she is 
discarded in a cruel and tragic way; ladyhood offers no protection against the rules of the patriarchal game.

The second but perhaps more compelling avatar figure of the Southern belle in The Counselor, is Malkina, a paragon of treacherous beauty and deadly power who instrumentalizes desire to fulfill her agenda of greed and power, dismantling norms of female gentility and love. She exaggerates the features of the Jezebel figure through her hyperbolic lust for money ${ }^{13}$. Like her older models, she is haunted by the past, and mourns the loss of a loved one. But she refuses to surrender to grief: for her, "tomorrow is another day" indeed! Independent, fearless, and ruthless, she charters the behavioral course for the lady in a posthuman context informed by the darwinian agenda of the global order and its power dynamics. She takes matters into her own hands, refusing to abide by notions of loyalty to her love interest: "When the axe comes through the door, I will be gone" she tells Reiner in a detached manner - emulating Scarlett's declaration of independence, but riding the horse rather than staying in the wagon... Her final lines - "the slaughter to come is beyond imagining" - constitute a chilling statement about our contemporary world, in keeping with current uses of the gothic mode as a tool to articulate topical issues and address the present rather than the past. This turn has become the norm in the post 9/11 imagination, as a recent issue of Gothic Studies demonstrated through a range of studies and insights into the corresponding cultural literary, cinematic, and visual production. ${ }^{14}$

The other protagonist on the stage of the plantation drama - the Southern gentleman -also undergoes revisionary work in recent releases which expose dimensions about the character that had been left implicit or concealed. The first avatar of the Southern gentleman characterized by a blend of refinement and violence in a modern context appears in Joel and Ethan Coen's 2007 adaptation of McCarthy's No Country for Old Men. Anton Chigurh, as a murderer, makes visible the deadly dimension of a code of honor that instrumentalizes others. Chigurh upholds his own logic, an economy of arbitrary moral cleansing that ends in an aporia: how to redeem humanity if you have already disposed of it? Before killing, he tells one of his victims "Would you hold still" in the incongruous balance between good manners and brutal acts to be performed, as in Flannery O'Connor's story "A Good Man is Hard to Find." In the scene with the gas station owner, the wrapper of the candy evokes the discarding of human beings undergirding the foundation of the South, making it "illegitimate" as Edouard Glissant shows in the aforementioned book. Chigurh's perverse ethos resonates with the Southern mystique of White Supremacy and its attending practices of murder, torture and terror. Lastly, Chigurh ushers in a new kind of Southern gentleman: he himself has turned into a killing machine. This dimension of the character looks resolutely to the future, and inscribes the figure in our current aesthetics of terrorism and posthumanism which blur the boundaries between humans and machines.

Under Tarantino's ruthless vision in Django Unchained, the Southern gentleman appears as a fraud. Calvin Candy's refined ways conceal a sadistic mind

13 For more on the Jezebel type, see Taina Tuhkunen "Belles, Jezebels and Other Dis/reputable Ladies: Southern Women on Screen" in Le Sud au cinéma, op. cit, p. 55-73.

14 See Marie Liénard-Yeterian and Agnieszka Soltysik Monnet, dirs. Gothic Studies: The Gothic in an Age of Terror(ism) 17/2. Novembre 2015. 
"beyond imagining" to use Malkina's image in The Counselor, in particular in his treatment of the old Mandingo fighter. His props - a hammer and a gun - implement an agenda of coercion and murder. The movie stages a theatre of cruelty that speaks to our contemporary addiction to violent images: the gentleman's agreement involves witnessing horror, and silencing terror. The unflinching gaze ushers the observer into the club of the privileges and trappings of power. Indeed, what is the price of silence? Is it to become an accomplice? But to see is to understand... and Schultz's refusal to shake hands breaks the spell - and the bond. He cannot turn the iconic gentleman agreement's gesture into a complete mockery of the values it is supposed to enact.

His act of resistance, however, results in the sacrifice of his life. In the end, it is the German visitor, former bounty hunter and outsider, who upholds a new narrative for the Southern gentleman. But his death suggests that the prospect of displacing the master narrative is still a remote one: the New South abides by some of the old codes indeed. Django's escape in the final scene heralds an uncertain fate for the survivors of the plantation collapse. His gallop into the night brings neither closure nor resolution; it is, perhaps, just a momentary respite from a form of chaos pervaded by contemporary interrogations about the uncanny future of the humanity in a world destroyed by fire (literal and symbolic) and hatred.

Another avatar figure of the Southern gentleman is proposed in The Counselor through the character of the lawyer who, despite the warning given to him, compromises with the world of "dirty money" in order to buy an expensive diamond for his beloved. In this ruthless economic jungle, the counselor's act of mercy for his client - in keeping with the traditional vision of the gentleman as purveyor of justice and order - cannot be processed by the Narcos who never believe his story. The truth, like human emotion, has no currency in their referential world, and chivalric ideals cannot be sustained in the face of the warfare triggered by greed. The sequence with the Mexican attorney exposes how loyalties develop to undermine the very core of legal practices which are supposed to punish corruption. The lawyers are expected to uphold the order of the Law, yet they participate in its demise through their ties to the Cartel that resemble a bobino-like mechanism destroying their body and soul. Machado's poetry looks like a temporary ornament - some entertainment on the Southern porch while, down below and far away in the fields, others toil away and die.

In addition, the Antebellum economy of commodities to be bought and sold haunts McCarthy's script set in the modern context of drug and human trafficking that function as a palimpsest to the ghosts from a past where the transformation of human beings into material goods triggered the "Southern curse," in William Faulkner's image, that brought about destruction and loss. The chivalric tradition echoed in Machado's poem tells a narrative of sorrow and grief: "I would give up everything to have one more hour with my beloved." Yet the gentlemanly counselor fails to protect his lady; he even becomes accessory to the demise of her purity, and her death. It is impossible to trade "places with her at the wheel," an arresting image of the violence done to women in the current context of drug cartels.

The film thus pries open the myth of love, and addresses the issue of free will and individual choice in our global economic and historic predicament. The contemporary Southern hero, like his elders, is plagued by the legacy of the collective 
past. The Mexican attorney's final words utter the sense of an ending that brings no catharsis, but more chaos and disarray. The counselor inherits the tragic gift of the violence that he initiated by compromising with the cartel logic. The greeting Hola written on the DVD sounds like the tragic oracle of words trusted beyond revising, emotions damaged beyond repair.

\section{The Civil War: Old and New Figures of Conflict}

As Louis Rubin notes, "History as a mode for viewing one's experience and one's identity remains a striking characteristic of the Southern literary imagination, black and white." ${ }^{15}$ The South on screen revisits the foundational historical events informing the imagination of the South. For example, the poetics of blood - which features frequently in literary fiction - fits within the legacy of taboos such as miscegenation, and the obsession that it generates. Such figure is endowed with a spectral quality functioning on the denotative and connotative levels, and is staged in particular in movies that deal with the Civil War.

One such recent example is The Hateful Eight (2015) where Tarantino's trademark use of violence goes beyond visual pyrotechnics to articulate the destructive and tragic elements of Southern history. The film allows Tarantino to return to the question of slavery and race explored in Django Unchained to tackle the legacy of decades of violence, discrimination and hatred in both the collective imagination and individual memory. The filmmaker uses the resources of the grotesque mode, calling on a type of comedy that comes with the baggage of terror. Even though the movie takes place in Wyoming, the action revolves around Civil War events and its unfinished business. The frontier is that of the unresolved conflicts left in the wake of the so-called "War between the states." The end of the war - the "unconditional surrender," as it is called in the film - has brought no closure. The action is set against a blizzard (not the hot sun of Westerns) and the pristine landscape of the West is obfuscated by a blanket of snow which gets in the way of the characters' moves and plans: the snow freezes, hampers, covers or betrays, yet it keeps track of the blood that has been shed - a curse for some, a blessing for others - in another metaphorical twist of the movie's physical cast.

The film opens with a shot of a wooden cross, and ends with the last two protagonists on the verge of dying after having read a letter allegedly written by Lincoln, and stained it with the blood of their murderous deeds. The President's words, recontextualized against the backdrop of the miniature war that has just been waged in the cabin, sound both preposterous and tragic. Hope and vision do seem to have missed the last coach into the light. There is no Western-like happy ending - just missed opportunities and hateful acts giving the lie to the promises of the American experience and political project. The opening shot functions like a tutorial in watching and understanding. A puzzling close-up triggers certain assumptions about what we are given to see: wood? The camera moves slowly backwards to propose another vantage point: we gradually realize that the disclosed wooden texture belongs to an arm, a face, a body. The wooden parts finally cohere into a sculpture representing Christ on the

15 See his book The History of Southern Literature, Baton Rouge, Louisiana State University Press, 1985. 
cross - a cross standing by a well-traveled track on the way to Minnie's haberdashery.

Other associations come to mind, and the viewer feels compelled to review previous assumptions as the large view conflicts with the initial vision. Likewise, the characters are not who and what they seem to one another and to the viewer at first sight. The usual tricks used by Tarantino - sudden unleashing of gruesome violence, understated dialogues, puppet-like characters, repulsive acts - are inscribed within an alternative embodiment of the Civil War on screen. Again, Kristeva's definition of the abject in The Powers of Horror is relevant to get the full measure of the spit, the vomit and the blood as we encounter them repeatedly and relentlessly. The gore pulls obvious and not so obvious strings about human cruelty and abuse, and about emotions such as resentment, revenge, pride, fear, and humiliation. The general is a convenient prop the murderers use to make the scene "more real" for the next episode of their deadly plan - a nod at Flannery O'Connor's story "A Late Encounter with the Enemy" where she explores the issue of the questionable relics Southerners sometimes cling to in their cult of the past: there is an allusion to the whole ritual of battle reenactments in the film, another token of the worship of a dead past that will not be laid to rest. The narration features chapters, a voice-over, flashbacks, embedded stories, and a claustrophobic atmosphere akin to a classical dramatic structure (one action, one day, one setting( that turn the movie into some Southern morality play pervaded by the posthuman aesthetics of gore and violence.

The unflagging exploration of evil in the context of a past that continues to haunt the nation - poised between the demons of Reservoir Dogs and those of Django Unchained - raises the following question: Did reconciliation come about then? Where are we at as a nation? More than ever the current context of the "house divided" image hovers above the numerous references to Lincoln and his era, his project and vision, in particular through his "letter" - a prop transformed into a trope. Like Anthony Minghella's 2003 Cold Mountain, the Civil War is used as a metaphoric narrative to discuss contemporary political divides in the wake of violent historical legacies - old and new.

No Country for Old Men presents the fratricide slaughter through the prism and trope of another kind on internecine war. The deadly conflicts entailed by drug cartels involve an alternative gallery of haves against have-nots, and the exploitation of the poor to fight the rich man's war all over again. The battlefield features new protagonists: the average citizen and the drug lords engaged in a territorial conflict - a struggle of "another kind" in Sheriff Bell's words. The suitcase that Moss has contains a device that connects it to Chigurh. The money, instead of ushering in a new life and opportunity, will soon become his death warrant. The piece of baggage literally comes with strings attached. This sense of destiny and doom resonates with the Southern notion of the curse. The contrast between refined manners and gruesome cruelty shown by some of the characters speaks to the paradoxes of the Antebellum world as we have analyzed them above. But the collapse into mad collective and individual violence, and its attendant, oblique reference to the Civil War (imagination of) disaster, bespeaks the horror and terror of the current world order.

A few years later, McCarthy's script for The Counselor reprises the thematic formula of the Civil War in an interesting way: some have seceded from the rule of 
law, creating a divided world, and their dominion is enforced through torture, terror, fear, mutilation, random kidnapping and killing - all forms of violence that resonate with the legacy of Southern history. The Civil War appears as a specter hovering above the contemporary forms of brutal warfare involving citizens of the same nation rather than inter-national conflicts, and provides an illuminating palimpsest to the posthuman imagination and consciousness.

The Civil War is thus ubiquitous in recent releases, under one guise or another, which bespeaks not only the current climate of political polarizing and cultural division over major societal issues, but also contemporary terrorist violence such as mass shootings. Moreover, recent releases have included alternative historical events to perform important cultural work in a context of heightened racial and gender violence. Nate Parker's 2016 film The Birth of a Nation rewrites the notorious Griffith movie that had set the standard for some of the most enduring imagery of the South on screen. It enacts a counter narrative about the "birth of a nation," and makes visible the deadly logic of a system turning others into property while uttering a topical caveat about the potentially destructive impact of rising anger all over the world ending in a blood bath. The Birth of a Nation calls forth the advent of a new kind of nation created in the wake of the global impact of inequality and poverty of our Anthopocene moment.

\section{Whither the South on Screen}

The function of art is avowedly to disturb, displace, stir consciousness and trigger awareness. In the movies studied here, there is a blend of rawness through the use of gory violence, and poetry through the elaborate dialogues, that sketch the contours of a landscape of disaster. The Southern aesthetics of the grotesque frequently used in the films - in particular through the handling of the bodily in torture, or murder (as in the beheading staged in The Counselor through the motorcycle accident scene) - speaks to individuals' visceral and animal impulses alienated from their rational and creative powers - the process Rosi Braidotti described with the image of "organs without bodies" mentioned above.

The final speech by Malkina at the end of The Counselor, in particular her ruthless suggestion that "We have to get rid of our sensibility," resonates with current debates around the posthuman condition. Her prediction that "the slaughter to come is beyond imagining" hints at topical forms of warmongering between humans in the wake of growing inequality, or even at some potential warfare between humans and machines... The other South delineated in the recent releases - perhaps a premonition of a South of the machine "Other" - proposes the ontological exploration of mankind pitted against the catastrophic consequences of today's plagues. In The Posthuman, Rosi Braidotti depicts this current predicament in the following way: "The most salient trait of contemporary global economy is its techno-scientific structure. It is built on the convergence between different and previously differentiated branches of technology, notably the four horsemen of the posthuman apocalypse: nanotechnology, biotechnology, information technology and cognitive science" (Braidotti 59). The cultural work performed by these films testifies to the power of the South on screen to envision the future instead of casting a backward glance - shaping the Southern 
tradition of storytelling into a cautionary tale, and negotiating the turn of prophecy instead of an oratory of anamnesis or amnesia.

\section{Works Cited}

Burke, James Lee. In the Electric Mist with the Confederate Dead. London: Orion, 1993. Print.

Braidotti, Rosa. The Posthuman. Cambridge and Malden: Politi Press, 2013. Print.

Campbell Jr., Edward D.C. The Celluloid South: Hollywood and The Southern Myth. Knoxville, The University of Tennessee Press, 1981. Print.

Darden, Gary Helm. "The New Empire in the 'New South': Jim Crow in the Global Frontier of High Imperialism and Decolonization." The Southern Quarterly 46.3 (Spring 2009): 8-25. Print.

Drew, Elizabeth. "Big Dangers for the Next Election." New York Review of Books LXII. 9, (May 21-June 3), 2015: 20-22.Print.

Dickey, James. Deliverance. New York: Delta, 1970. Print.

French, Warren, ed. The South and Film, Jackson, University Press of Mississippi, 1981. Print.

Glissant, Edouard. Faulkner, Mississippi. Paris: Editions Stock, 1995. Print.

Graham, Allison. Framing the South: Hollywood, Television, and Race during the Civil Rights Struggle. Baltimore and London, The Johns Hopkins University Press, 2001. Print.

Gray, Richard. A Web of Words: The Great Dialogue of Southern Literature. Athens and London: The University of Georgia Press, 2007. Print.

Heider, Karl G. ed. Images of the South: Constructing a Regional Culture on Film and Video. Athens and London: The University of Georgia Press, 1993. Print.

Kirby, Jack Temple. Media-Made Dixie: The South in the American Imagination. Baton Rouge: Louisiana State University Press, 1978. Print.

Kristeva, Julia. The Powers of Horror: An Essay on Abjection. New York: Columbia University Press, 1982. Print.

Langman, Larry, and David Ebner, eds. Hollywood's Image of the South: A Century of Southern Films. Westport, Conn.: Greenwood Press, 2001. Print.

Liénard-Yeterian, Marie, and Taina Tuhkunen, eds. Le Sud au cinéma : de The Birth of a Nation à Cold Mountain, Palaiseau, Editions de l'Ecole polytechnique, 2009. Print.

Liénard-Yeterian, Marie. "Angel or Demon: Performing the South in Cinema." In Le Sud au cinéma, 37-53. Print.

"No Country for Old Men de Cormac McCarthy: Des mots aux images." Nouvelles du Sud: Hearing Voices, Reading Stories. Eds. Liénard-Yeterian, Marie and Gérald Préher. Palaiseau: Editions de l'Ecole polytechnique, 2012. 261-271. Print.

. and Agnieszka Soltysik Monnet, ed. Gothic Studies: The Gothic in an Age of Terror(ism) 17/2. Novembre 2015. Print.

. "Gothic Trouble: Cormac McCarthy's The Road and the Globalized Order." In Text Matters: A Journal of Literature, Theory and Culture (6), special issue 
titled Gothic Matters edited by Agnieszka Soltysik Monnet, 2016: 144-158. Print.

McCarthy, Cormac. No Country for Old Men. New York: Vintage International, 2005. Print. . The Road. New York: Vintage International, 2006. Print.

McPherson, Tara. Reconstructing Dixie: Race, Gender, and Nostalgia in the Imagined South. Durham and London: Duke University Press, 2003. Print.

O'Connor, Flannery. The Complete Stories. New York: Farrar, Straus and Giroux, 1972. Print.

Rubin, Louis, ed. The History of Southern Literature. Baton Rouge: Louisiana State University Press, 1985. Print.

Smith, Lilian. Killers of the Dream. (1949) New York: Norton, 1994. Print.

Taylor, Helen. Circling Dixie: Contemporary Southern Culture Through a Transatlantic Lens. Piscataway: Rutgers University Press, 2001. Print.

Ward, Jesmyn. Sing, Unburied, Sing. London: Bloomsbury Circus, 2017. Print.

Zinn, Howard. The Southern Mystique. (1959) Cambridge: South End Press, 2002. Print.

\section{Films Cited}

Cold Mountain. Dir. Anthony Minghella. Perf. Nicole Kidman, Jude Law, and Renee Zellweger. Miramax Films, 2003.

Deliverance. Dir. John Boorman. Perf. Burt Reynolds, Jon Voight, and Ned Beatty. Warner Bros, 1972.

The Beguiled. Dir. Don Siegel. Perf. Clint Eastwood, Geraldine Page Elizabeth Harman, and Jo Ann Harris. Universal Pictures, 1971.

The Beguiled. Dir. Sofia Coppola. Perf. Colin Farrell, Nicole Kidman, Kirsten Dunst, Elle Fanning. American Zoetrope, 2017.

The Birth of a Nation. Dir. Nate Parker. Perf. Nate Parker, Armie Hammer, Aja Naomi King, Gabrielle Union. Bron Studios/Mandalay Pictures 2016.

The Hateful Eight. Dir. Quentin Tarentino. Perf. Samuel L. Jackson, Kurt Russell, Jennifer Jason Leigh, and Walton Goggins. The Weinstein Company, 2015.

The Mule. Dir. Clint Eastwood. Perf. Clint Eastwood, Bradley Cooper, Laurence Fishburne, and Alison Eastwood. Malpaso Productions/ Warner Bros. 2018.

The Road. Dir. John Hillcoat. Perf. Viggo Mortensen, Kodi Smit-McPhee, Charlize Theron, and Robert Duvall. 2929 Productions, 2009.

No Country for Old Men. Dir. Joel and Ethan Coen. Perf. Javier Bardem, Josh Brolin, Tommy Lee Jones, and Kelly Macdonald. Paramount Vantage/Miramax Films, 2007. 